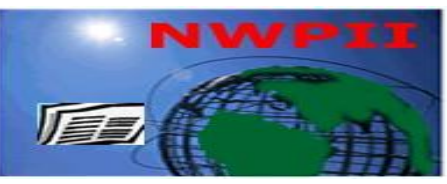

American Journal of Biomedical Sciences

ISSN: 1937-9080

nwpii.com/ajbms

\title{
The involvement of androgens in human hair growth
}

\author{
Saeed A. Alwaleedi* \\ Biology Department, Faculty of Science, Taif University (TU), Taif, Saudi Arabia \\ *Corresponding author \\ Saeed Alwaleedi \\ Biology Department \\ Faculty of Science \\ Taif University (TU) \\ Taif, Saudi Arabia \\ E-mail: swaleedi@hotmail.com
}

Received: 15 March 2015; $\mid$ Revised: 25 May 2015; | Accepted: 1 June 2015

\begin{abstract}
Androgens are an important regulator of human hair growth. Human hair follicles in various sites of the body have a variable individual, inherited susceptibility for androgen dependent growth. Androgens regulate the type of hair produced in human follicles, which can cause psychological distress in cases of excess large hairs, e.g. in hirsutism, male hair distribution in women, or reduced visible hairs, e.g. in androgenetic alopecia, male pattern baldness. These disorders are poorly controlled and cannot currently be effectively treated, mainly due to our lack of understanding of hair follicle function. The molecular mechanisms of the androgen action in human hair follicles are not well understood. Changes in hair follicle and hair size are believed to involve signalling between the hair follicle components via paracrine factors. It is believed that androgens exert their effects on hair follicles via the mesenchyme-derived dermal papilla cells by altering the regulatory paracrine factors produced by the dermal papilla itself and affect the other follicular components. Identifying key paracrine factors which may be involved in androgen regulated changes in the hair follicles could improve our understanding of the mechanism of androgen action in human hair follicles. Better understanding of this mechanism and the structure, functions of hair follicles should lead to better treatment for hair disorders such as hirsutism and androgenetic alopecia.
\end{abstract}

Keywords: Hair follicles, androgens, androgenetic alopecia, hirsutism, paracrine factors

\section{Introduction}

\subsection{Hair \& its importance}

Mammals have hair all over their bodies as a unique character which differentiates them from other animals in the Animal Kingdom [1]. Most human skin produces hair, except for some particular parts of the body, the glabrous skin, including the lips, palms of the hands and soles of the feet [2]. Hairs are greatly variable in colour, diameter, length, and cross-sectional shape [3]. There are three main types of hair: lanugo, vellus and terminal. Lanugo hair is soft and fine, and is formed in foetal life. This type of hair starts 
growing on human embryo skin at about the $20^{\text {th }}$ week of pregnancy, and then sheds in uterus at about the $36^{\text {th }}$ week of pregnancy. After birth, an infant has two types of hair, vellus and terminal. Vellus hair is short, small, fine, unmedullated and unpigmented hair. It is located in areas of the body described as hairless regions, for instance the facial hair of a child or adult women [4]. Terminal hair is long, thick and pigmented, often with a medullated hair shaft. It grows on various parts of the human body such as the scalp, face, eyelashes, eyebrows, arms, legs and axillae [5,6]. The main functions of human hair are protection and communication. For example, eyebrows and eyelashes protect eyes from incoming objects [7]. Scalp hair protects the head and neck from the harmful effects of sunlight, ultraviolet light, cold and physical damage [8]. In addition, scalp hair provides insulation for the head due to the lack of adipose tissue on the scalp. Thermoregulatory function is less important in human beings, however the small amount of terminal hair on the human body helps to cool the body through evaporation from sweat glands [9]. One of the most important functions of human hair is social and sexual communication. Hair plays a role in beauty; strong healthy hair indicates good health to others, whereas sparse and brittle growth of the hair indicates poor nutrition and bad health [10]. Hair removal generally has strong depersonalizing roles, for instance shaving prisoners and Christian or Buddist monks, while long uncut hair has positive connotations like strength and its association with religion in Sikhs [11]. There are clear differences in hair type and distribution between males and females, and between adults and children. The growth of pubic and axillary hair is a sign of maturation and puberty [6,12].

In addition, hair disorders such as hirsutism or excessive hair growth and alopecia or hair loss can have negative effects on the quality of life such as social restriction and psychological distress to those who suffer from them [11]. Although hair loss is not life threatening in human beings, the important communication roles of hair explain its importance for most people [13]. Since hair plays a vital role in a person's appearance, self-image and communication, this provides an insight into why it is possible for hair growth disorders to be at the root of serious psychological distress [14]. Unfortunately, many hair disorders cannot currently be effectively treated, mainly due to our lack of understanding of hair follicle function. Therefore a greater understanding of the mechanisms regulating hair growth, leading to the control of these conditions is of great interest worldwide.

\subsection{Hair structure}

Hair is a fully keratinised flexible structure of epithelial cells which originates from hair follicles that extend down to various lengths into the dermis and often into the subcutaneous adipose tissue [15]. The hair follicle has a complex structure which results from epithelialmesenchymal interactions initiated around the 3rd month of embryonic development [16]. A typical hair consists of two main parts (fig 1); the first part is the hair shaft which is located above the level of the epidermis and is formed of a type of protein called keratin. The other part is the hair root which is enclosed within the hair follicle under the level of the epidermis [17].

The bottom of the follicle is the hair bulb where the epithelial cells surround the mesenchyme-derived dermal papilla, a pearshaped structure located within its centre. The dermal papilla plays an important role throughout the hair follicle development and life cycle, as it contains specialised fibroblasts, known as dermal papilla cells, which are surrounded by extracellular matrix containing mucopolysaccharides and basement membrane proteins [18,19]. The dermal papilla is almost completely surrounded by the epithelial matrix, except a small gap at the base of the hair bulb, to allow blood vessels and nerves to enter the papilla. The non-cellular part of the dermal papilla includes collagen types I and III, and fibronectin. The size of the dermal papilla and its cells is proportional to the size of the hair follicle, and therefore the hair fibre produced [20].

\subsection{Hair growth cycle}

The hair follicle grows in cycles. However, hair cycles in human beings do not occur at the 
same time for all hairs. Morphologically, the hair cycle process is well understood, but is still not clarified at the molecular level. Each hair cycle consists of successive stages of growth and involution, which include tissue regression and regeneration. The hair growth cycle includes three main stages: the growth phase, anagen, the transitional phase, catagen, and the resting phase, telogen [21]. A fourth phase, exogen, is involved in releasing the old hair via an active enzymatic releasing process $[22,23]$. The duration of each stage varies between species. Overall, the hair follicle exhibits a highly complex organised architecture and represents an attractive experimental system because of its accessibility, dispensability and self-renewal capacity [3].

\section{Androgens and human hair growth}

The hair follicle growth cycle allows the hair produced from the follicle to change and adapt to seasonal variation or changes in sexual development. The mechanisms involved in the complicated processes of the hair growth cycle are not well understood. In mammals, seasonal variation can be detected in the changing of coat thickness and colour induced by temperature, day length, and nutrient availability [24]. These changes in the environment are translated to the follicle via the endocrine system, mainly through the pineal and hypothalamus-pituitary route $[25,6]$. The hormones involved differ between the species, but generally include gonadal hormones, thyroid hormones, corticosteroids, prolactin, and melanocyte stimulating hormone.

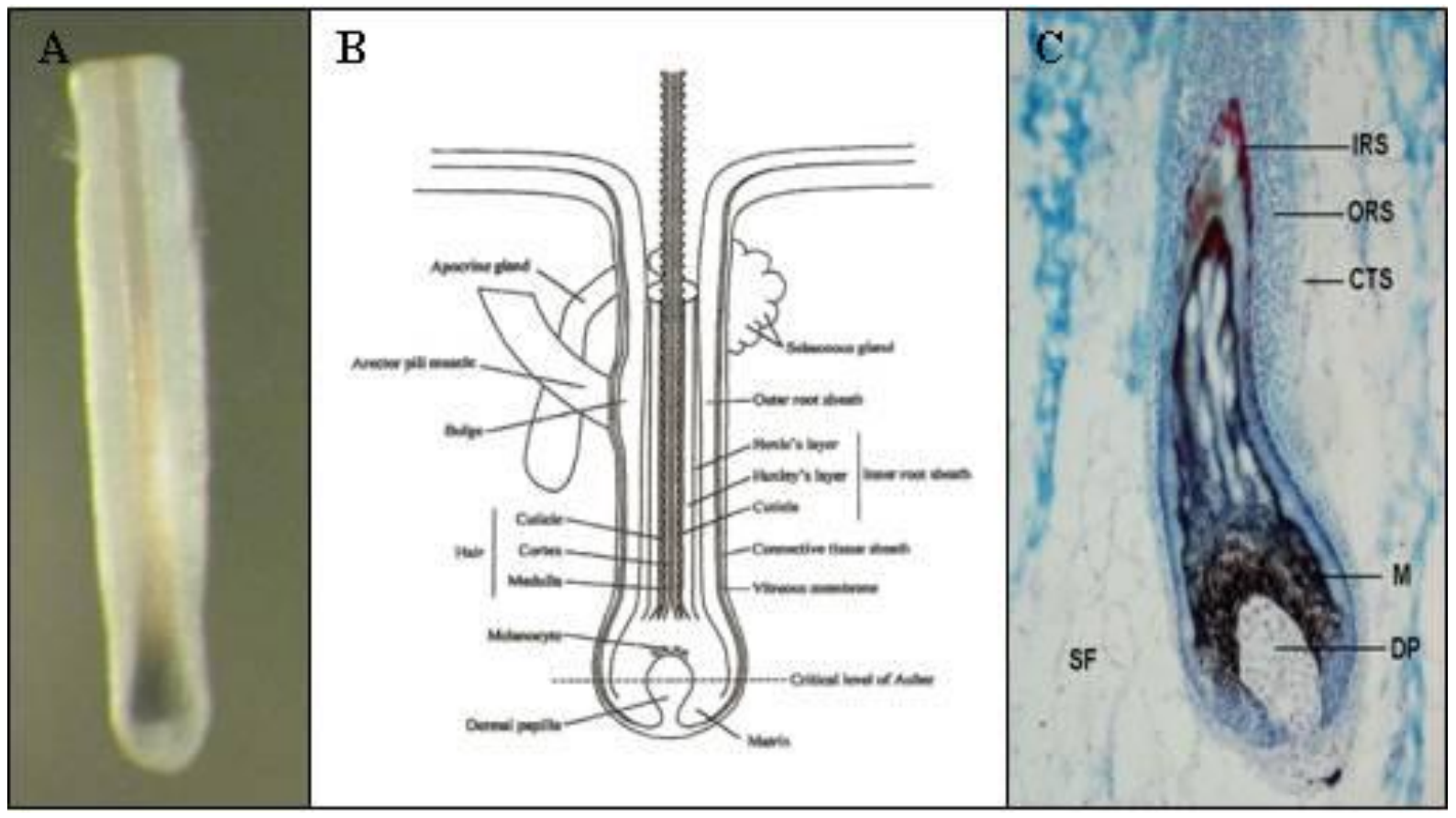

Fig 1. The structure of human hair follicle. Isolated human scalp hair follicle (A), schematic diagram (B) and longitudinal section (C) showing the human hair follicle and associated structures. The outer root sheath (ORS), the inner root sheath (IRS), the connective tissue sheath (CTS), and the hair shaft (HS). The hair bulb extends deep within the skin and includes the dermal papilla (DP) which is surrounded by the hair matrix (M). 


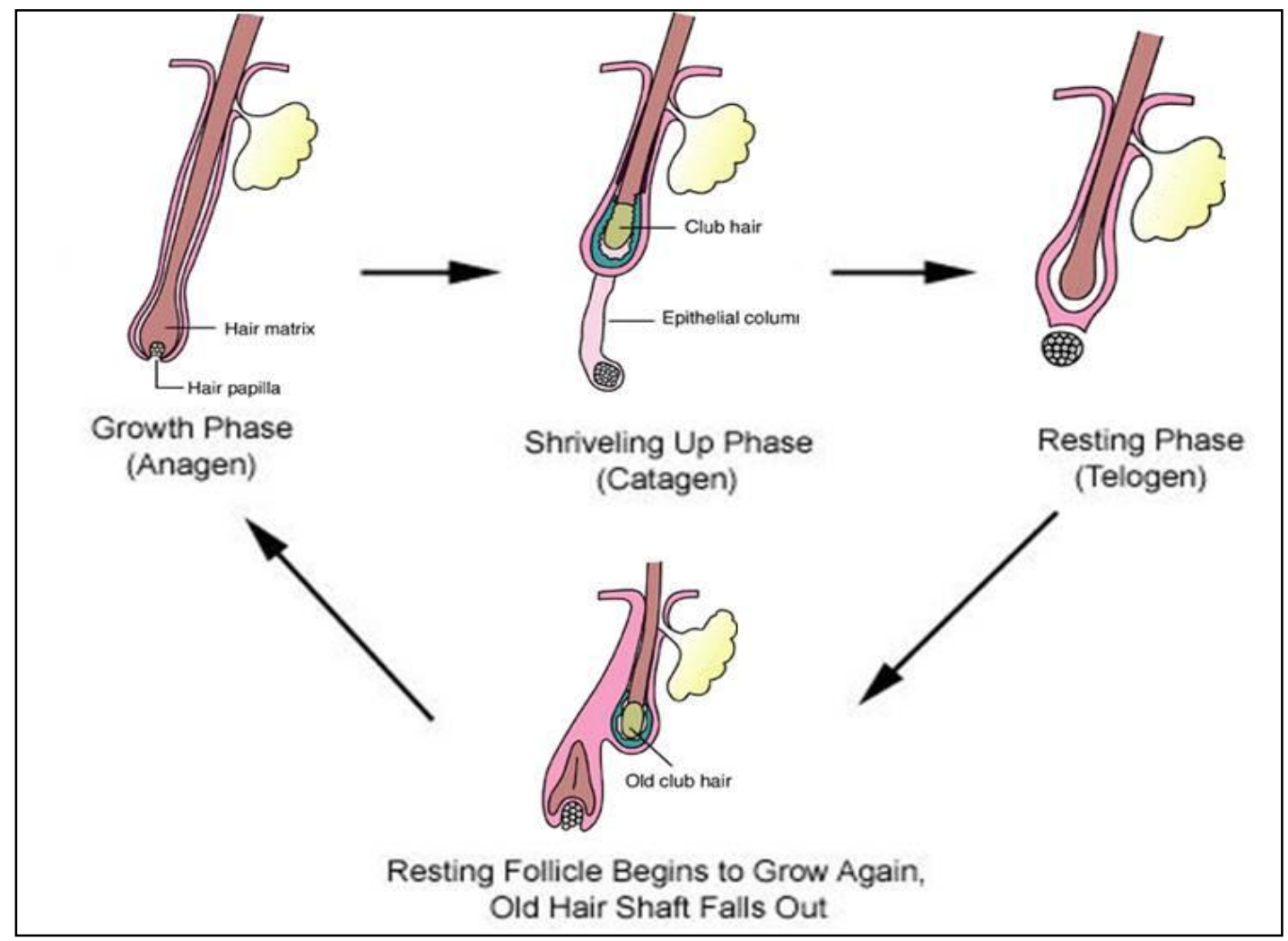

Fig 2. Hair growth cycle. Diagram represents the successive phases of human hair growth cycle including anagen, catagen, telogen and exogen. Reproduced with a kind permission from the BMJ publishing group.

In human beings, a few weeks after birth a wave of hair shedding occurs [26], after this the hair cycle is asynchronous except for the local groups of three follicles called DeMijère trios. Circannual variation in the rate of the human hair growth has been observed on the scalp, thigh, and beard [27]. Hair growth in human beings is affected by various factors such as glucocorticoids [28], thyroid hormones [29], pregnancy [30], circulating hormones [6] and nutrient levels [31]. However, androgens are the major regulating hormones of hair growth [11]. Human hair follicles, which are distributed in various parts of the body, have an innate tendency for androgen-dependent growth [32]. Almost all human hair follicles are influenced by androgens except some specific areas of the body which produce terminal hair in childhood such as eyelashes, eyebrows, and many scalp follicles where androgens have no obvious effect [2].
Androgens can exert opposite functions in human hair growth depending on the body site (fig 3). They can transform small vellus hair follicles into large terminal hair follicles, as seen during the growth of beard, pubic hair, and axillary hair after puberty [12], whereas they can also transform large terminal hair follicles into small vellus hair follicles as seen on the scalp in genetically predisposed individuals with androgenetic alopecia (male pattern baldness) in which the follicles undergo progressive miniaturisation [32]. These paradoxical effects of androgens on human hair growth have long been a mystery. These changes occur gradually with several hair growth cycles occurring before the type of hair produced is changed [33]. In addition, these changes appear to be androgen dependent and determined by the presence of sufficient circulating androgens [34], as well as the degree of genetic predisposition [32]. 
One of the first signs of puberty is the gradual replacement of small vellus hair with larger, more pigmented hair in the pubis and axillae in both sexes [12]. These changes parallel the rise in plasma androgens which occurs earlier in girls than in boys [35]. During male puberty, the growth of beard initially starts in the moustache area and the middle of the chin and later spreads over the lower part of the face and parts of the neck [12]. In Japanese and Caucasian men, beard and axillary hair both grow rapidly, however while beard growth continues until the seventies, axillary hair growth peaks in the midtwenties and then decreases rapidly in both races [36]. This indicates that the hair follicles in different anatomical locations of the body have different responses and sensitivities to androgen. However, the range of responses of hair follicles to androgens is genetically intrinsic [32] and depends upon body site [37], as well as levels of circulating androgens, for example beard hair growth in males needs much higher levels of androgens than post-pubertal axillary and pubic hair in females. The effects of androgens on hair growth are clearly illustrated by patients with testicular feminisation who have no functional androgen receptors. These individuals do not develop beards, axilla or pubic hair. There have been no reports of these patients suffering from androgenetic alopecia [38].

\subsection{Androgen-related hair disorders}

Because of its importance in social and sexual communications, hair plays an important role in the standard of a person's appearance and self-image. Therefore, hair disorders may cause psychological distress and reduced quality of life. However, hair disorders are not physically painful or life threatening. The two main androgen-related problems associated with hair growth are the loss of hair on the scalp in males and females, which is more prevalent in males (androgenetic alopecia), and excessive hair growth on the face and body of women in the male pattern (hirsutism).

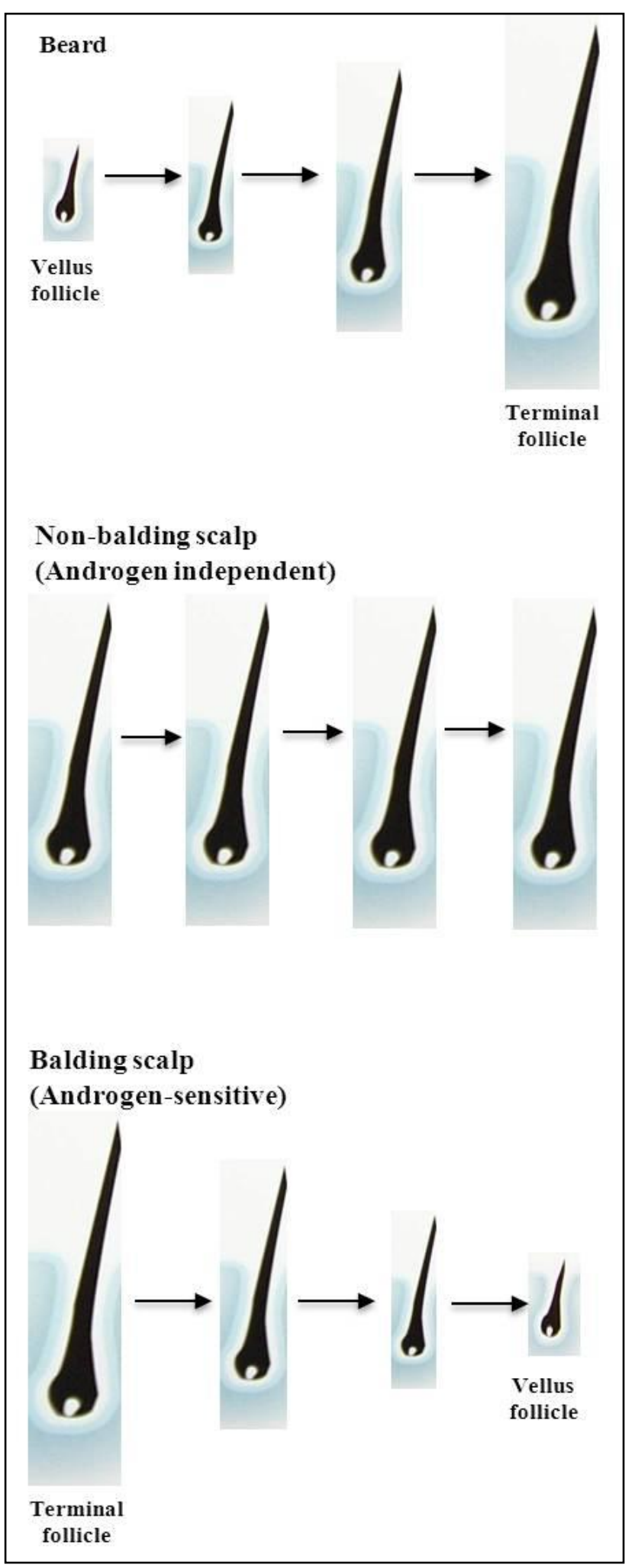

Fig 3. Effects of androgens on human hair follicles. Schematic diagram represents the paradoxical effects of androgens on human hair follicles of different body sites. 


\subsubsection{Androgenetic alopecia}

Androgenetic alopecia is a common type of hair loss. It is also called common baldness or male pattern baldness which mainly affects men [39], but can also affect women [40]. Androgenetic alopecia affects up to half of the male Caucasian population by middle age and almost all Caucasian men in old age [41]. This type of hair disorder is characterised by the gradual transformation of thick, pigmented hairs on the scalp to short, thin pale hairs, in both men and women [33]. In androgenetic alopecia and also during puberty, the gradual changes in the type of hair produced by the hair follicles are related to changes in the stages of the hair growth cycle [6]. Therefore, during the disorder progression, the anagen phase of hair growth cycle shortens whereas the telogen phase remains constant [33].

The distinctive pattern of hair loss was first described by [39]. The hair loss severity was classified into seven classes (fig 4), starting from pre-pubertal scalp (Type I) through gradual recession of bitemporal hairline and thinning of the vertex (Type VII). This classification system was later modified to improve the grading of the middle balding types. This type of male pattern baldness can occur in women (fig 5), however a different pattern of hair loss is more common. It was described and graded by [42] as the gradual hair loss in the crown, with preservation of the frontal hair line [43].

There are two main factors involved in the pathogenesis of androgenetic alopecia including androgen and genetic predisposition. There is a great deal of evidence to support the involvement of androgen in the development of androgenetic alopecia. For example, androgenetic alopecia does not occur in male castrated prior to puberty and progression is stopped if postpubertal males are castrated [44]. In castrated men, hair loss can be stimulated using testosterone replacement therapy, however withdrawal of the hormone led to a cessation in hair loss progression [34]. The role of androgen in hair loss is confirmed by the absence of androgenetic alopecia in people with complete androgen insensitivity syndrome in which individuals lack functional androgen receptors [38]. In balding men, testosterone levels are normal [45] and the response to androgen seems to be intrinsic to the hair follicle [33]. Genetic predisposition is required for the onset of alopecia alongside androgen [46]. Androgenetic alopecia has been described as an autosomal dominant trait with variable penetrance [47]. A number of genes have been investigated for an association with androgenetic alopecia, it has been reported that male-pattern baldness associated with genetic variants in the androgen receptor gene [48]. In addition, recent studies showed susceptibility variants for androgenetic alopecia on chromosome 20p11 [49]. This indicates that the inheritance pattern of androgenetic alopecia seems to be polygenic.

There are a range of treatments for androgenetic alopecia such as surgery, wigs and hairpieces, hormonal, and non-hormonal therapy. The surgical treatments are based on the intrinsic response of hair follicles to androgens. It involves the relocation of hair follicles from the nonbalding occipital and parietal areas of the scalp to cover the bald sites [50]. This type of treatment is long lasting, painful and expensive, as well as it may require further surgery as the hair loss develops around the transplanted regions. The main hormonal treatments include anti-androgens and $5 \alpha$-reductase inhibitors. Anti-androgen treatment blocks the androgen binding to the androgen receptors; however, this is not a desirable treatment for men as it has impractical effects on male masculinity. $5 \alpha$-reductase inhibitors, such as finasteride, act by blocking the conversion of testosterone to its more active form $5 \alpha$-dihydrotestosterone (DHT) which binds the same receptor as testosterone. It has been observed that finasteride slowed down gradual hair loss and promoted hair growth in men under 42 with stage II to V hair loss [51]. Another study showed the efficacy of finasteride in older men [52]. Recently, it has been revealed that dutasteride, a type I and type II $5 \alpha$-reductase inhibitor, increased scalp hair growth in men with androgenetic alopecia more rapidly than finasteride, which only inhibits type II $5 \alpha$ reductase [53]. To date, $5 \alpha$-reductase inhibitors are the best current treatment for androgenetic alopecia in men, however similar to all hormonal treatments, they require long-term continuation. 
The most commonly used non-hormonal treatment for androgenetic alopecia in men and women is minoxidil [54]. It belongs to a group of drugs known as potassium channel openers. It was initially developed for hypertension treatment, but it was observed to have hypertrichosis (excessive hair growth) as a common side effect [55] and then it was remarketed as a hair loss treatment. It is unclear how minoxidil itself functions to stimulate hair growth, however a recent study suggested that the mechanism of minoxidil action in hair follicle is via the opening the ATP-sensetive potassium channels in the membranes of hair follicle cells [56].

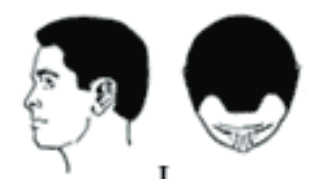

I

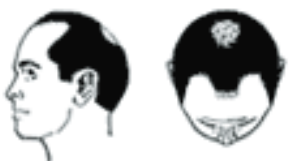

III Vertex

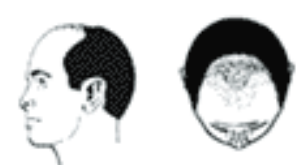

IV A

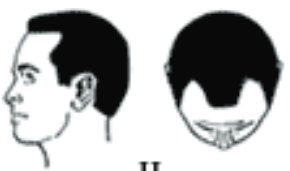

II

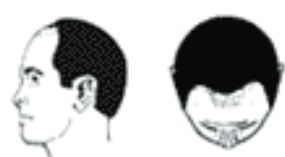

II A

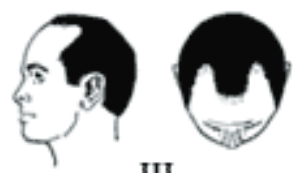

III

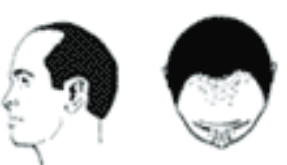

III A

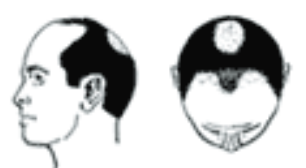

IV

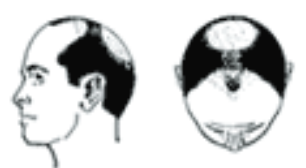

V

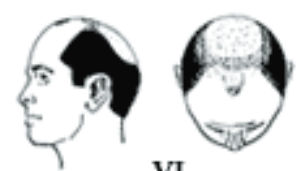

VI

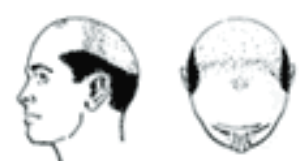

VII

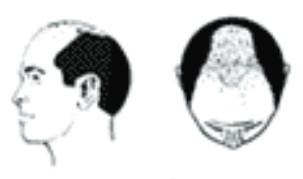

VA

Figure 4. The pattern of hair loss in androgenetic alopecia in men. The Hamilton scale [39], as modified by Norwood, is used to classify the type and extent of common baldness in men.

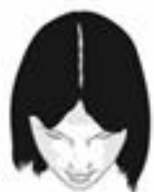

$1-1$

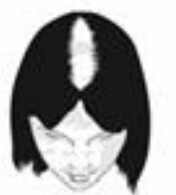

$1-4$

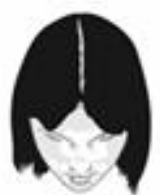

I-2

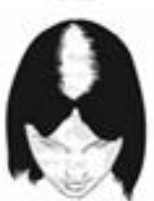

II- 1

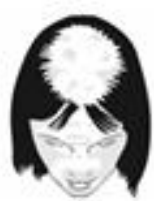

III

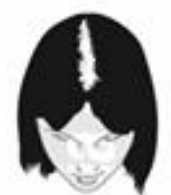

$1-3$

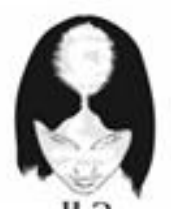

II-2
Figure 5. The pattern of hair loss in androgenetic alopecia in women. This type of hair loss was described and graded by [42] as the gradual hair loss in the crown, with preservation of the frontal hair line.

\subsubsection{Hirsutism}

Hirsutism is the excessive hair growth on areas of the body of women in the pattern of a normal post-pubertal male [57]. In normal women, these sites of the body are covered by fine hair for instance above the lip, on the chin, chest, forearms, back and abdomen. This abnormal hair growth may be triggered by excess production of androgen. In these cases androgens cause the transformation of fine, small hairs into thick, pigmented hairs. This is a paradoxically different effect of androgens compared to their involvement in androgenetic alopecia. It has been reported in a study investigating hirsutism in British women between 15 and 64 years of age, that about $10 \%$ have hair on the chest, $22 \%$ on the chin, and $49 \%$ on lips [58]. There are several conditions which can cause hirsutism such as polycystic ovary syndrome (PCOS) which is 
characterised by excessive production of androgen [59]. However, a small portion of cases have idiopathic hirsutism, with no detectable hormonality [60].

Treatment of hirsutism can involve cosmetic and/or pharmacological approaches. Pharmacological methods include treatment with anti-androgen drugs such as cyproterone acetate (CPA), spironolactone [61] and flutamide (FLU) [62]. This type of treatment may take 6-9 months before detecting any effect on hair growth and there may only be partial improvement. In addition, there is also a risk of feminisation of a male foetus with anti-androgen treatment [63]. Finasteride is also used as a competitive inhibitor of $5 \alpha$-reductase, and has been shown to be effective for treating hirsutism with fewer side effects [64]. The cosmetic approach employs various methods which physically remove or lighten excess hair to make it less conspicuous; such treatment includes shaving, waxing, bleaching, depilatory creams, electrolysis and laser hair removal [65].

\subsection{Mechanism of androgen action in the hair follicle}

The main circulating androgen in the human body is testosterone which is derived from cholesterol like other steroid hormones. Testosterone is primarily made and secreted by leydig cells in the testes of human men and the ovaries of women; the adrenal glands in both sexes can also secrete low level of androgens. However, the amounts of testosterone produced by human males are much more than those produced by females [66]. In addition, the concentration of circulating testosterone produced by males is estimated as 10-35 nmol whereas it is $<3.5 \mathrm{nmol}$ in females [67]. Androgens are carried in the blood either free or bound to specific proteins such as albumin, and sex-hormone binding globulin (SHBG) [68].

Systemic androgens can enter the hair follicle via its blood vessels into the dermal papilla and the dermal sheath. Because androgens are lipid soluble (lipophilic molecules), they can diffuse directly from the blood into the cytoplasm of target cells through the cell membrane and then enter the nucleus [69]. In the cytoplasm, testosterone can be metabolised to $5 \alpha$ dihydrotestosterone (DHT) depending on the site of the follicle in the presence of the enzyme $5 \alpha$ reductase. Androgens exert their activities on the target cells by binding to specific intracellular receptors. Each receptor contains a ligandbinding site and DNA-binding site. Both testosterone and $5 \alpha$-dihydrotestosterone can bind to the ligand-binding domain, which causes a conformational change in the receptor, as well as activation of the DNA binding site [70]. However, 5 $\alpha$-dihydrotestosterone is a more potent androgen and binds to the androgen receptor with a higher affinity than testosterone to modulate gene expression [71]. The receptorandrogen complex then binds to a specific DNA sequence of the target gene which is called a hormone response element [72]. This binding process results in activation of androgendependent genes, and DNA transcription which leads to altering the production of specific proteins (fig 6 and 7).

\subsubsection{Androgen insensitivity syndrome}

The mechanism of androgen action in hair follicles has been illustrated by various forms of androgen insensitivity syndrome. Individuals with this syndrome are characterised by an XY genotype but they exhibit a female external phenotype. These individuals lack functional androgen receptors. Although they have normal or raised circulating androgen levels, they lack beard, pubic, and axillary terminal hair and they do not undergo androgen-dependent scalp hair thinning [38]. This confirms that the terminal hair growth in these sites of the body is androgen dependent, whereas follicles in other sites such as scalp, eyebrows, and eyelashes are androgen independent.

\subsubsection{The enzyme $5 \alpha$-reductase}

Two isoforms of the enzyme $5 \alpha$-reductase type I and type II, have been identified [73]. The distribution of these isoenzymes varies between tissues, however both types are found in scalp follicles [74] and a recent study showed that the genes for $5 \alpha$-reductase type I and type II were expressed in cultured dermal papilla cells derived from both beard and scalp hair follicles [75]. 
Type I is mainly found in the liver, however its role is not obvious. Absence of $5 \alpha$-reductase type II results in the syndrome of $5 \alpha$-reductase deficiency, a rare form of male pseudohermaphroditism. Individuals with this syndrome are born genetic males (XY) with ambiguous external genitalia and they are unable to convert testosterone [76]. Individuals with $5 \alpha-$ reductase type II deficiency do not produce male patterns of body hair, in spite of their circulating androgens after puberty. They only produce female patterns of pubic and axillary hair and show an absence or reduction of beard growth, although they do develop a masculinized male body shape [77]. This suggests that pubic and axillary follicles respond to testosterone, but the male secondary sexual hair growth demands metabolism of testosterone to $5 \alpha$ dihydrotestosterone [6]. It is unclear why some follicles require testosterone and others $5 \alpha$ dihydrotestosterone to induce the same cell biological changes. This suggests that the cells use different intracellular coactivating proteins to act with the receptor [11].

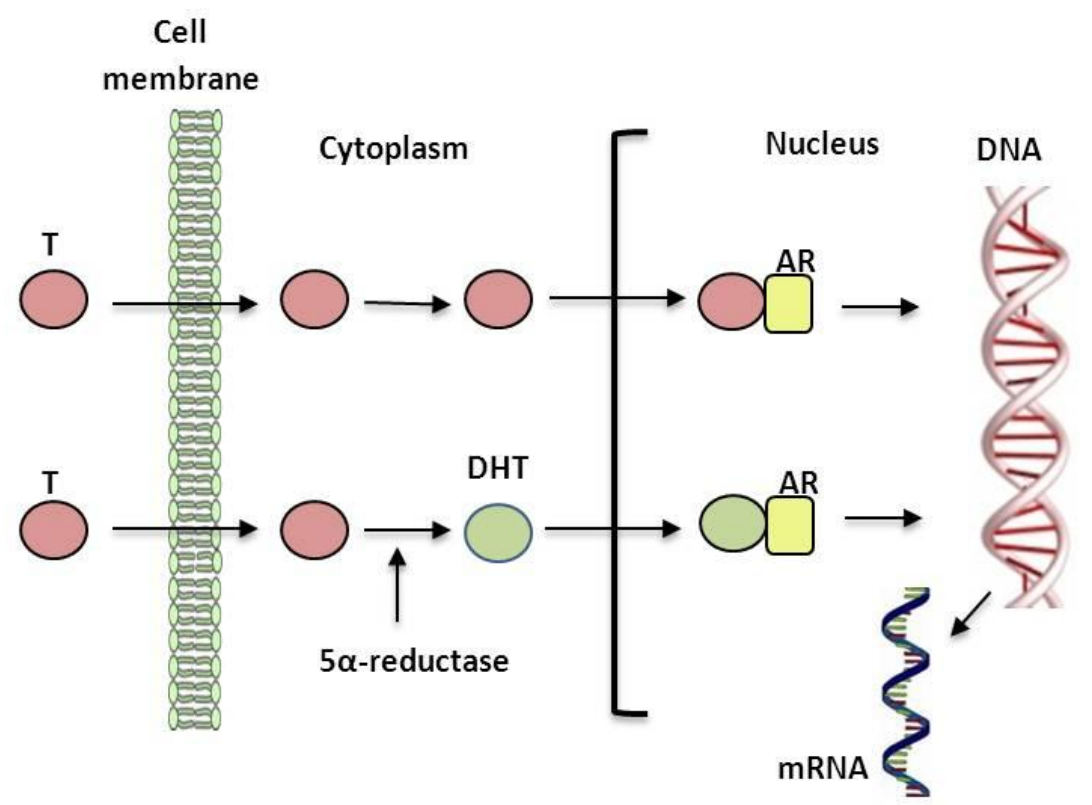

Figure 6. The mechanism of androgen action. Schematic diagram represents the mechanism of action of testosterone (T) and 5 $\alpha$-dihydrotestosterone (DHT). AR: androgen receptor.

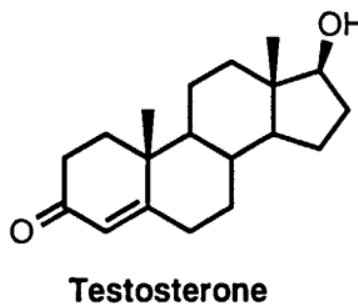

Testosterone

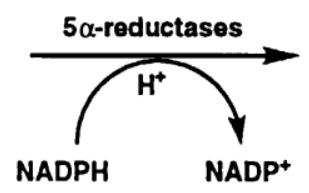

NADPH

NADP+

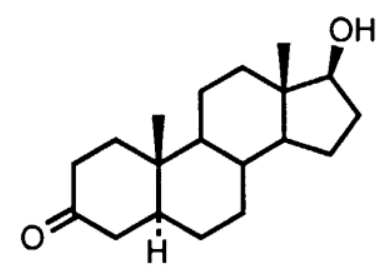

Dihydrotestosterone

Figure 7. Conversion of testosterone to dihydrotestosterone in the presence of $5 \alpha$-reductase enzyme 


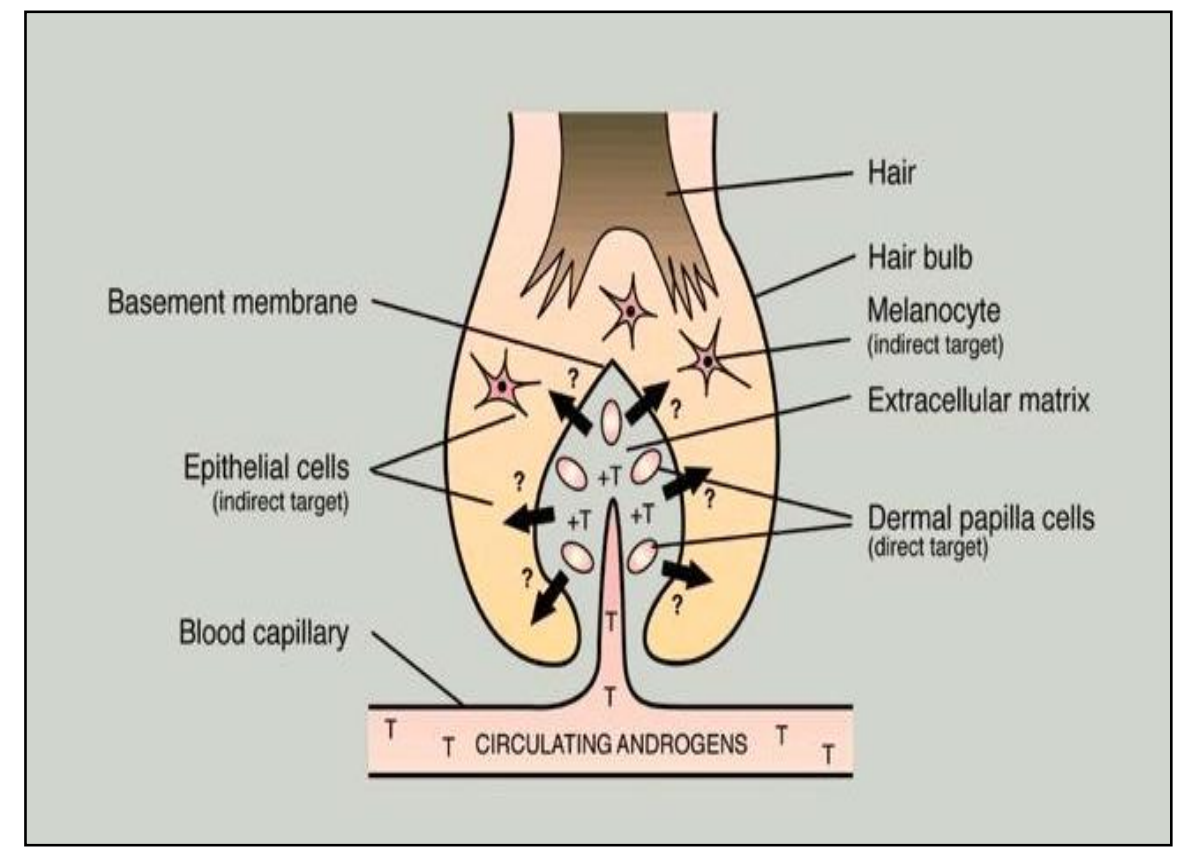

Fig 8. Diagrammatic representation of androgen action in the hair follicles. Circulating androgens enter the dermal papilla via its blood capillaries, causing the production of paracrine factors which act on other follicular components [78]. T: Testosterone, ?: unknown paracrine factors.

\subsection{Current hypothesis of androgen action in hair follicles}

The molecular mechanisms involved in the control of hair growth are not well understood. Androgens are the major regulating hormones of human hair growth [11]. It is believed that androgens act on the hair follicle via the mesenchyme-derived dermal papilla which interprets the response indirectly for the other follicular components. The current hypothesis of androgen action in hair follicles was proposed by [78]. This hypothesis proposed that circulating androgens enter the dermal papilla via its welldeveloped blood supply. Within the dermal papilla cells of androgen dependent hair follicles, androgens bind to specific intracellular androgen receptors and then cause alteration in their production of paracrine factors. These factors then act on other components of the hair follicles, altering the type of hair produced (fig 8).

Paracrine factors are those for which the target cells are different from, but near to the signal-releasing cell. These factors could be soluble mitogenic factors such as growth factors and/or extracellular matrix components. Elucidation of these factors may lead to a better understanding of hair biology and the mechanisms involved in androgen dependent hair disorders. These factors may act on different follicular targets including the melanocytes which modify the amount of pigments produced, the keratinocytes which propagate to produce the hair fibre and different sheaths, and the follicular endothelial cells and the cells of the follicular connective tissue sheath [6,11]. In addition, another possible target for these factors could be the dermal papilla itself via an autocrine regulatory system [79], as any change in the dermal papilla size leads to a change in hair follicle size and the type of hair produced $[20,80]$. Therefore, the dermal papilla cells would be the direct target for androgen action, whereas the other follicular components would be controlled by androgens indirectly.

This hypothesis has received much support by several experimental studies. Using autoradiographic localisation, the highest concentrations of radio-labelled testosterone were detected in the dermal papilla cells and sebaceous glands in rat skin. This indicates that these cells are the main androgen targets of skin [81]. It has been reported that androgen receptors are 
localised in human dermal papilla cells, but not hair follicle keratinocyte cells [82,83]. Based on in vitro studies, dermal papilla cells derived from androgen-sensitive regions, such as human balding scalp and beard, contain higher levels of specific, saturable androgen receptors than those derived from androgen-insensitive regions such as non-balding scalp [84]. This is also reflected in the red deer follicles where androgen receptors have been localised by immunohistochemistry in the dermal papilla cells derived from mane follicles taken during the breeding season, whereas they were not detected in those taken during non-breeding season [85]. The gene for the androgen receptor was expressed in cultured human dermal papilla cells taken from axillary and beard hair follicles, whereas it was only present at a low level in cells derived from occipital scalp hair [86]. This parallels individuals without functional androgen receptors, i.e, with androgen insensitivity syndrome, who exhibit no beard, axillary, and pubic terminal hair, and do not develop androgenetic alopecia [38]. This indicates that the dermal papilla plays a main role in androgenmediated effects in the hair follicles.

Further evidence implicating the dermal papilla as an androgen target is that $5 \alpha$-reductase type II mRNA was expressed in the dermal papilla and the dermal sheath cells from both balding and non-balding scalp follicles [87]. Based on in vitro study, the metabolism of testosterone has also been examined, and varies between dermal papilla cells taken from different body sites. Cultured dermal papilla cells from non-balding scalp, beard, pubic and axillary follicles were incubated with radio-labelled testosterone. All cells and media contained testosterone and androstenedione, but only beard dermal papilla cells contained the metabolite $5 \alpha$ dihydrotestosterone $[88,89]$.

References [90,91] used a co-culture system of dermal papilla cells and outer root sheath cells to investigate the DNA synthesis level. They observed an increase in DNA synthesis measured by ${ }^{3} \mathrm{H}$-thymidine uptake compared to cells cultured separately. Addition of testosterone stimulated ${ }^{3} \mathrm{H}$-thymidine uptake in the co-culture system of both beard and axillary dermal papilla cells with outer root sheath cells. However, there was no effect for testosterone on cells cultured alone, or in the co-culture of occipital scalp dermal papilla cells and outer root sheath cells. In addition, the stimulation of ${ }^{3} \mathrm{H}$-thymidine uptake under the influence of testosterone was antagonised by the addition of anti-androgen, cyproterone acetate. This strongly suggests that the stimulatory effects in the co-culture system of both beard and axillary were mediated via an androgen receptor pathway.

The production of paracrine factors by cultured dermal papilla cells was examined in the presence and absence of androgen [92]. Conditioned media produced by cultured dermal papilla cells derived from beard, balding and nonbalding scalp were collected. All media promoted DNA synthesis in epithelial cell line of human skin. After incubation with testosterone, media from balding scalp dermal papilla cells had a reduced ability to induce the epithelial cell growth compared to untreated media from nonbalding, balding, and beard dermal papilla cells. This may have been due to the production of inhibitory paracrine factors under the influence of testosterone.

Another study used a similar experimental design to examine the production of paracrine and autocrine factors by androgen-insensitive non-balding scalp and androgen-sensitive beard dermal papilla cells [89]. The conditioned media by the dermal papilla cells were collected and its effects on ${ }^{3} \mathrm{H}$-thymidine incorporation into other dermal papilla cells were investigated. From the study it was found that both non-balding and beard dermal papilla conditioned media have inducible effect for both cell types, but the response to the factor was greater in beard dermal papilla cells. After incubation with testosterone, the production of mitogenic factors was only increased with the conditioned media from beard dermal papilla cells. It was observed that only beard dermal papilla cells were able to respond to these factors. This suggested that both cell types secreted autocrine factors and the testosterone stimulation of autocrine factors production by beard dermal papilla cells in vitro reflected the response of these cells to androgens in vivo. 
The production of inhibitory autocrine factors by balding dermal papilla cells was investigated by [79]. This study revealed that conditioned medium, produced by dermal papilla cells derived from either non-balding or balding scalp had growth promoting effect on nonbalding scalp dermal papilla cells in vitro. However, balding medium was found to stimulate to a lesser extent. In addition, only conditioned medium from non-balding scalp stimulated rat vibrissae dermal papilla cells, and no significant stimulation was seen with conditioned medium from balding scalp. This was due to the secretion of soluble inhibitory factors by balding cells and this study also revealed that the conditioned medium from balding dermal papilla cells inhibited mouse hair growth in vivo, indicating that this medium contained inhibitory autocrine factors.

\section{Paracrine factors in the hair follicle}

The development of epithelial appendages demands cell signaling and interaction between epithelial cells, and between epithelia and mesoderm-derived dermis [93]. It is believed that cell signals may play a key role in regulation of cell growth, cell differentiation and epithelial appendage formation [94]. Polypeptide growth factors are a variety of proteins which play important roles in the regulation of cell growth, movement and differentiation, and perform their activities, for example control cell proliferation and differentiation, by binding to specific membrane receptors on the cell membrane to transduce the growth factor signals [95]. The identification of paracrine factors produced by dermal papilla cells in androgen dependent follicles has been the focus of much research. A number of growth factors and cytokines have been implicated in the regulation of the hair follicle $[96,97]$. Only some of these have been implicated in androgen action so far, generally by studying cultured dermal papilla cells; the main ones include:

Insulin-like growth factor-I (IGF-I) is a highly potent mitogen which maintains cultured anagen scalp hair follicles at physiological concentrations in vitro [98]. Abnormal patterns of hair growth and differentiation have been observed when IGF-I actions were blocked in the IGF-I receptor deficient mouse [99]. Reference [100] observed an increase in gene expression of IGF-I when beard dermal papilla cells were cultured with testosterone in vitro. They also reported that androgens increased the proliferation of outer root sheath cells when cocultured with dermal papilla cells in vitro. This stimulation by androgens was intercepted when IGF-I action was blocked using antibodies.

Transforming growth factor- $\beta 1$ (TGF- $\beta 1$ ) is another possible paracrine factor which inhibits hair growth in vitro and may play a role as a negative regulator of hair follicle growth [97]. In organ culture, it has been found that TGF- $\beta 1$ inhibits human hair growth in vitro [101]. Reference [102] used a co-culture system to investigate TGF- $\beta 1$ in dermal papilla cells of balding scalp with transfected androgen receptors and keratinocytes. When a synthetic androgen was added to the culture, a significant inhibition was noticed in keratinocyte growth. They also found that TGF- $\beta 1$ was induced by androgen in cultured balding dermal papilla cells. Furthermore, the inhibition of keratinocyte growth was reversed using anti-TGF- $\beta 1$-antibody in a dose-dependent manner. This suggests that androgens stimulate the expression of TGF- $\beta 1$ in balding dermal papilla cells leading to inhibition of epithelial cell growth. TGF- $\beta 1$ has also been implicated in the control of catagen. Premature catagen was induced when TGF- $\beta 1$ was injected into the back skin of mice [103] and a suppressor of TGF- $\beta 1$ delayed the progression of catagen in mice [104]. Androgen also stimulated balding cultured dermal papilla cells to produce TGF- 32 [105] which is associated with the transition from anagen to catagen in human hair follicles in vitro [106]. Therefore, androgen stimulation of dermal papilla production of TGF- $\beta$ could shorten anagen.

Another possible androgen-sensitive paracrine factor is Stem cell factor (SCF), also called c-kit ligand, mast cell growth factor or steel factor. SCF is known to play a main role in development of epidermal [107] and hair pigmentation [108]. Dermal papilla cells derived from beard, non-balding and balding scalp 
follicles can produce SCF [109]. However, beard cells secrete more SCF than those from nonbalding scalp suggesting that androgens may increase the production of SCF by beard dermal papilla cells leading to formation of darker facial hair [110]. Similarly, cells derived from the paler balding follicles secreted less SCF than normal scalp cells [109]. The SCF receptor, c-kit, was expressed in adult scalp hair follicle melanocytes [111]. This suggests that changes in the amount of SCF produced by the dermal papilla cells may alter hair pigmentation by acting on the hair follicle melanocytes.

Vascular endothelial growth factor (VEGF) is another possible paracrine factor which acts as a modulator of angiogenesis and vascular permeability. Anagen terminal hair follicles have a good vascular system, suggesting microvascular angiogenesis may occur at an early stage of every new anagen phase [112]. The gradual changes in the size of androgen-responsive follicles, for instance during puberty, are reflected in the different size of their blood vessels. It has been reported that cultured dermal papilla cells express the gene for VEGF [113]. Cultured dermal papilla cells derived from catagen and telogen follicles of human scalp were found to express low levels of VEGF using in situ hybridization [114]. Recently, it has been found that the levels of VEGF were decreased in patients undergoing androgen deprivation therapy for prostate cancer compared to its levels before treatment indicating an androgen-regulation of VEGF expression [115]. Better understanding of these factors should elucidate androgen action in hair follicles and therefore lead to the development of treatments for androgen dependent hair disorders such as androgenetic alopecia and hirsutism.

\section{Conclusion}

The hair follicle exhibits a highly complex organised architecture and represents an attractive experimental system because of its accessibility, dispensability and self-renewal capacity. The hair follicle consists of structures derived from ectodermal and mesenchymal origins. Epithelial and mesenchymal interactions are important for both hair follicle development and cycling. The mesenchyme-derived dermal papilla is an important feature of hair follicle development and a permanent, discrete entity throughout the hair cycle of the hair follicle. The dermal papilla is believed to be the main regulator of the hair follicle and can determine what sort of hair is produced. It is believed that androgens act on hair follicles through the dermal papilla. Androgens are the main known key regulator responsible for changing the type of hair produced by a hair follicle, stimulating enlarged follicles producing larger terminal hair in many areas after puberty and as seen in hirsutism, while causing reduction in follicle size on the scalp resulting in androgenetic alopecia. The alteration of the size of the hair produced by a hair follicle, while at the same time maintaining many processes involved in hair growth and the hair cycle, probably requires a number of paracrine factors, some of them are inhibitory and others stimulatory. In this model, circulating androgens enter the dermal papilla through its good blood supply and cause alteration in its production of paracrine regulatory factors, which influence the surrounding follicular components. These factors would play a role in altering the type of hair produced by androgen-dependent hair follicles. Paracrine factors may target the follicular melanocytes which control the amount of pigment produced, the keratinocytes which proliferate to produce the hair fibre, the follicular endothelial cells, and the cells of the connective tissue sheath, as well as the dermal papilla itself through an autocrine regulatory system. Investigating these factors could give us a better understanding of the mechanisms involved in androgen-dependent hair disorders. Therefore a greater understanding of the mechanisms regulating hair growth could lead to better treatment for hair disorders.

\section{References}

1. Porter, R. M. (2003). Mouse models for human hair loss disorders. J Anat 202, 125 131. DOI: $10.1046 / \mathrm{j} .1469-7580.2003 .00140 . \mathrm{x}$ 
2. Ebling, F. J. (1986). Hair follicles and associated glands as androgen targets. Clin Endocrinol Metab 15, 319-339.

DOI: $10.1016 / \mathrm{S} 0300-595 \mathrm{X}(86) 80028-7$

3. Schlake, T. (2007). Determination of hair structure and shape. Semin Cell Dev Biol 18, 267-73.

DOI: 10.1016/j.semcdb.2007.01.005

4. Blume, U., Ferracin, J., Verschoore, M., Czernielewski, J. M., and Schaefer, H. (1991). Physiology of the vellus hair follicle: hair growth and sebum excretion. $\mathrm{Br} \mathrm{J}$ Dermatol 124, 21-28.

DOI: 10.1111/j.1365-2133.1991.tb03277.x

5. Gray, J., and Dawber, R. (1998). Hair and scalp disorders. Blackwell Science Inc, Boston, USA.

6. Randall, V. A. (2007). Hormonal regulation of hair follicles exhibits a biological paradox. Semin Cell Dev Biol 18, 274-85.

DOI: 10.1016/j.semcdb.2007.02.004

7. Martini, F. H. (1998). The integumentary system, In Fundamentals of anatomy and physiology (Prentice Hall, New Jersey), pp. 148-161.

8. Costin, G. E., and Hearing, V. J. (2007). Human skin pigmentation: melanocytes modulate skin color in response to stress. Faseb J 21, 976-994.

DOI: 10.1096/fj.06-6649rev

9. Ebling, F. J. G. (1985). The mythological evolution of nudity. J Human Evol 14, 33-41. DOI: 10.1016/S0047-2484(85)80093-2

10. Bradfield, R. B. (1971). Protein deprivation: comparative response of hair roots, serum protein, and urinary nitrogen. Am J Clin Nutr 24, 405-410.

11. Randall, V. A. (2008). Androgens and hair growth. Dermatol Ther 21, 314-328.

DOI: 10.1111/j.1529-8019.2008.00214.x

12. Marshall, W. A., and Tanner, J. M. (1970). Variations in the pattern of pubertal changes in boys. Arch Dis Child 45, 13-23.

DOI: $10.1136 /$ adc. 45.239 .13

13. Jansen, V. A., and van Baalen, M. (2006). Altruism through beard chromodynamics. Nature 440, 663-666.

DOI: $10.1038 /$ nature 04387
14. Gulec, A. T., Tanriverdi, N., Duru, C., Saray, Y., and Akcali, C. (2004). The role of psychological factors in alopecia areata and the impact of the disease on the quality of life. Int J Dermatol 43, 352-356.

DOI: 10.1111/j.1365-4632.2004.02028.x

15. Montagna, W. (1976). General review of the anatomy, growth, and development of hair in man. In: Biology and diseases of the hair, international symposium on biology and disease of the hair. Tokyo, Japan, October 69, 1975. Eds. Kobori, T. and Montagna, W. University Park press, Baltimore, PP 21-31.

16. Hardy, M. H. (1992). The secret life of the hair follicle. Trends Genet 8, 55-61. DOI: 10.1016/0168-9525(92)90350-D

17. Slobodan, M., and Snezana, V. (1998). The control of hair growth. Dermatology Online Journal 4, 2.

18. Couchman, J. R., King, J. L., and McCarthy, K. J. (1990). Distribution of two basement membrane proteoglycans through hair follicle development and the hair growth cycle in the rat. J Invest Dermatol 94, 65-70.

DOI: $10.1111 / 1523-1747 . e p 12873363$

19. Jahoda, C. A. (1992). Induction of follicle formation and hair growth by vibrissa dermal papillae implanted into rat ear wounds: vibrissa-type fibres are specified. Development 115, 1103-1109.

20. Elliott, K., Stephenson, T. J., and Messenger, A. G. (1999). Differences in hair follicle dermal papilla volume are due to extracellular matrix volume and cell number: implications for the control of hair follicle size and androgen responses. J Invest Dermatol 113, 873-877.

DOI: 10.1046/j.1523-1747.1999.00797.x

21. Alonso, L., and Fuchs, E. (2006). The hair cycle. J Cell Sci 119, 391-393.

DOI: $10.1242 / \mathrm{jcs} 02793$

22. Stenn, K. (2005). Exogen is an active, separately controlled phase of the hair growth cycle. J Am Acad Dermatol 52, 374-375.

DOI: 10.1016/j.jaad.2004.07.040

23. Higgins, C. A., Richardson, G. D., Westgate, G. E., and Jahoda, C. B. (2009). Exogen involves gradual release of the hair club fibre 
in vibrissa follicle model. Exp Dermatol 18, 793-795.

DOI: 10.1111/j.1600-0625.2008.00833.x

24. Galbraith, H. (1998). Nutritional and hormonal regulation of hair follicle growth and development. Proc Nutr Soc 57, 195-205. DOI: $10.1079 /$ PNS19980032

25. Ebling, F. J., Hale, P. A., and Randall, V. A. (1991). Hormones and hair growth, In Biochemistry and physiology of the skin, L. A. Goldsmith, ed. (Clarenden Press, Oxford), pp. 660-690.

26. Pecoraro, V., Astore, I., and Barman, J,M. (1968). The pre-natal and post-natal hair cycles in man, In Biopathology of pattern alopecia, A. Baccaredda-Boy, Moretti, G., and Frey, J.R., ed. (Karger, Basel), pp. 29-38.

27. Courtois, M., Loussouarn, G., Hourseau, S., and Grollier, J. F. (1996). Periodicity in the growth and shedding of hair. Br J Dermatol 134, 47-54.

DOI: 10.1111/j.1365-2133.1996.tb07839.x

28. Stenn, K. S., Paus, R., Dutton, T., and Sarba, B. (1993). Glucocorticoid effect on hair growth initiation: a reconsideration. Skin Pharmacol 6, 125-134.

DOI: $10.1159 / 000211097$

29. Van Beek, N., Bodo, E., Kromminga, A., Gaspar, E., Meyer, K., Zmijewski M.A., Slominski, A., Wenzel, B.E., and Paus, R. (2008). Thyroid hormones directly alter human hair follicle functions: anagen prolongation and stimulation of both hair matrix keratinocyte proliferation and hair pigmentation. J Clin Endocrinol Metab 93, 4381-4388. DOI: 10.1210/jc.2008-0283

30. Lynfield, Y. L. (1960). Effect of pregnancy on the human hair cycle. J Invest Dermatol 35, 323-327. DOI: 10.1038/jid.1960.54

31. Rushton, D. H. (2002). Nutritional factors and hair loss. Clin Exp Dermatol 27, 396-404. DOI: 10.1046/j.1365-2230.2002.01076.x

32. Nyholt, D. R., Gillespie, N. A., Heath, A. C., and Martin, N. G. (2003). Genetic Basis of Male Pattern Baldness. 121, 1561-1564. DOI: 10.1111/j.1523-1747.2003.12615.x

33. Randall, V. A. (2005). Physiology and pathophysiology of androgenetic alopecia, In Endocrinology, L. J. Degroot, and Jameson,
J.L., ed. (Philadelphia: W B Saunders Co.), pp. 3295-3309

34. Hamilton, J. B. (1942). Male hormone stimulation is a prerequisite and an incitant in common baldness. Am J Anat 71, 451-481. DOI: 10.1002/aja.1000710306

35. Winter, J. S., and Faiman, C. (1972). Pituitary-gonadal relations in male children and adolescents. Pediatr Res 6, 126-135. DOI: 10.1203/00006450-197202000-00006

36. Hamilton, J. B. (1958). Age, sex, and genetic factors in the regulation of hair growth in man: a comparison of Caucasian and Japanese populations, In The biology of hair growth, W. Montagna, and Ellis, R.A., ed. (Academic Press, New York), pp. 399-433. DOI: 10.1016/B978-1-4832-3287-4.50022-2

37. Randall, V. A., and Ebling, F. J. (1991). Seasonal changes in human hair growth. Br J Dermatol 124, 146-151. DOI: 10.1111/j.1365-2133.1991.tb00423.x

38. McPhaul, M. J. (2004). Androgen receptors and androgen insensitivity syndromes, In Endocrinology, L. J. Degroot, and Jameson, J.L., ed. (Philadelphia: W B Saunders Co).

39. Hamilton, J. B. (1951). Patterned loss of hair in man; types and incidence. Ann N Y Acad Sci 53, 708-728.

DOI: 10.1111/j.1749-6632.1951.tb31971.x

40. Messenger, A. G., and Sinclair, R. (2006). Follicular miniaturization in female pattern hair loss: clinicopathological correlations. $\mathrm{Br}$ J Dermatol 155, 926-930.

DOI: 10.1111/i.1365-2133.2006.07409.x

41. Ellis, J. A., and Harrap, S. B. (2001). The genetics of androgenetic alopecia. Clin Dermatol 19, 149-154.

DOI: $10.1016 / \mathrm{S} 0738-081 \mathrm{X}(00) 00125-5$

42. Ludwig, E. (1977). Classification of the types of androgenetic alopecia (common baldness) occurring in the female sex. Br J Dermatol 97, 247-254.

DOI: 10.1111/j.1365-2133.1977.tb15179.x

43. Biondo, S., Goble, D., and Sinclair, R. (2004). Women who present with female pattern hair loss tend to underestimate the severity of their hair loss. Br J Dermatol 150, 750-752.

DOI: 10.1046/j.0007-0963.2003.05809.x 
44. Hamilton, J. B. (1960). Effect of castration in adolescent and young adult males upon further changes in the proportions of bare and hairy scalp. J Clin Endocrinol Metab 20, 1309-1318. DOI: 10.1210/jcem-20-10-1309

45. Pitts, R. L. (1987). Serum elevation of dehydroepiandrosterone sulfate associated with male pattern baldness in young men. $\mathrm{J}$ Am Acad Dermatol 16, 571-573.

DOI: 10.1016/S0190-9622(87)70075-9

46. Birch, M. P., and Messenger, A. G. (2001). Genetic factors predispose to balding and non-balding in men. Eur J Dermatol 11, 309314.

47. Bergfeld, W. F. (1955). Androgenetic alopecia: An autosomal dominant disorder. Am J Med 98, 955-985.

48. Prodi, D. A., Pirastu, N., Maninchedda, G., Sassu, A., Picciau, A., Palmas, M. A., Mossa, A., Persico, I., Adamo, M., Angius, A., and Pirastu, M. (2008). EDA2R is associated with androgenetic alopecia. J Invest Dermatol 128, 2268-2270. DOI: 10.1038/jid.2008.60

49. Richards, J. B., Yuan, X., Geller, F., Waterworth, D., Bataille, V., Glass, D., Song, K., Waeber, G., Vollenweider, P., Aben, K. K., et al. (2008). Male-pattern baldness susceptibility locus at 20p11. Nat Genet 40, 1282-1284. DOI: $10.1038 / n g .255$

50. Epstein, J. S. (2007). Evolution of techniques in hair transplantation: a 12-year perspective. Facial Plast Surg 23, 51-59.

DOI: $10.1055 / \mathrm{s}-2007-970164$

51. Kaufman, K. D., Olsen, E. A., Whiting, D., Savin, R., DeVillez, R., Bergfeld, W., Price, V. H., Van Neste, D., Roberts, J. L., Hordinsky, M., et al. (1998). Finasteride in the treatment of men with androgenetic alopecia. Finasteride Male Pattern Hair Loss Study Group. J Am Acad Dermatol 39, 578589. DOI: 10.1016/S0190-9622(98)70007-6

52. Whiting, D. A., Olsen, E. A., Savin, R., Halper, L., Rodgers, A., Wang, L., Hustad, C., and Palmisano, J. (2003). Efficacy and tolerability of finasteride $1 \mathrm{mg}$ in men aged 41 to 60 years with male pattern hair loss. Eur J Dermatol 13, 150-160.

53. Olsen, E. A., Hordinsky, M., Whiting, D., Stough, D., Hobbs, S., Ellis, M. L., Wilson,
T., and Rittmaster, R. S. (2006). The importance of dual 5alpha-reductase inhibition in the treatment of male pattern hair loss: results of a randomized placebocontrolled study of dutasteride versus finasteride. J Am Acad Dermatol 55, 10141023. DOI: 10.1016/j.jaad.2006.05.007

54. Messenger, A. G., and Rundegren, J. (2004). Minoxidil: mechanisms of action on hair growth. Br J Dermatol 150, 186-194. DOI: 10.1111/j.1365-2133.2004.05785.x

55. Dawber, R. P., and Rundegren, J. (2003). Hypertrichosis in females applying minoxidil topical solution and in normal controls. J Eur Acad Dermatol Venereol 17, 271-275. DOI: 10.1046/j.1468-3083.2003.00621.x

56. Shorter, K., Farjo, N. P., Picksley, S. M., and Randall, V. A. (2008). Human hair follicles contain two forms of ATP-sensitive potassium channels, only one of which is sensitive to minoxidil. FASEB J 22, 17251736. DOI: $10.1096 /$ fj.07-099424

57. Azziz, R. (2003). The evaluation and management of hirsutism. Obstet Gynecol 101, 995-1007.

DOI: $10.1016 / \mathrm{S} 0029-7844(02) 02725-4$

58. Ehrmann, D. A. (2005). Polycystic ovary syndrome. N Engl J Med 352, 1223-1236.

DOI: $10.1056 / \mathrm{NEJMra041536}$

59. Franks, S. (1989). Polycystic ovary syndrome: a changing perspective. Clin Endocrinol 31, 87-120.

DOI: 10.1111/j.1365-2265.1989.tb00457.x

60. Elghblawi, E. (2008). Idiopathic hirsutism: excessive bodily and facial hair in women. $\mathrm{Br}$ J Nurs 17, 192-197.

DOI: $10.12968 /$ bjon.2008.17.3.28410

61. Shapiro, J., and Lui, H. (2005). Treatments for unwanted facial hair. Skin Therapy Lett $10,1-4$.

62. Osculati, A., and Castiglioni, C. (2006). Fatal liver complications with flutamide. Lancet 367, 1140-1141. DOI: 10.1016/S0140-6736(06)68498-5

63. Hughes, B. R., and Cunliffe, W. J. (1988). Tolerance of spironolactone. Br J Dermatol 118, 687-691.

DOI: 10.1111/j.1365-2133.1988.tb02571.x 
64. Moghetti, P., Tosi, F., Tosti, A., Negri, C., Misciali, C., Perrone, F., Caputo, M., Muggeo, M., and Castello, R. (2000). Comparison of spironolactone, flutamide, and finasteride efficacy in the treatment of hirsutism: a randomized, double blind, placebo-controlled trial. J Clin Endocrinol Metab 85, 89-94. DOI: 10.1210/jc.85.1.89

65. Claman, P., Graves, G. R., Kredentser, J. V., Sagle, M. A., Tan, S., Tummon, I., and Fluker, M. (2002). Hirsutism: evaluation and treatment. J Obstet Gynaecol Can 24, 62-73, 77-69.

66. Baird, D. T. (1970). The secretion of androgens and estrogens from the ovary and adrenal gland. In: Reproductive Endocrinology. Irvine W.J. \& Lorraine J.A. (Editors). Livingstone, Edinburgh. pp 95-99.

67. Leshin, K. J., and Wilson, J. D. (1981). Mechanisms of androgen-mediated hair growth. In: Hair Research. Springer-Verlag, Berlin. pp 205-209.

DOI: $10.1007 / 978-3-642-81650-5 \_29$

68. Rommerts, F. F. G. (2004). Testosterone: An overview of biosynthesis, transport, metabolism and nongenomic actions, In Testosterone action - deficiency substitution, E. Nieschlag, and Behre, H.M., ed. (Cambridge University Press), pp. 1-37.

69. Randall, V. A., Hibberts, N. A., Thornton, M. J., Hamada, K., Merrick, A. E., Kato, S., Jenner, T. J., De Oliveira, I., and Messenger, A. G. (2000). The hair follicle: a paradoxical androgen target organ. Horm Res 54, 243250. DOI: $10.1159 / 000053266$

70. Narayanan, R., Mohler, M. L., Bohl, C. E., Miller, D. D., and Dalton, J. T. (2008). Selective androgen receptor modulators in preclinical and clinical development. Nucl Recept Signal 6, 10-26.

71. Randall, V. A. (1994). The role of $5 \alpha-$ reductase in health and disease. In: Hormones, enzymes and receptors., $\mathbf{M}$. Sheppard and P. Stewart, eds. pp. 405-431.

72. Handelsman, D. J. (2005). Androgen action and pharmacologic uses. In: Endocrinology, De Groot L.J.D and Jameson L., eds. (Philadelphia: WB Saunders Co), pp. 31213138.
73. Blanchard, Y., Seenundun, S., and Robaire, B. (2007). The promoter of the rat 5alphareductase type 1 gene is bidirectional and Sp1-dependent. Mol Cell Endocrinol 264, 171-183. DOI: 10.1016/j.mce.2006.11.007

74. Eicheler, W., Dreher, M., Hoffmann, R., Happle, R., and Aumuller, G. (1995). Immunohistochemical evidence for differential distribution of 5 alpha-reductase isoenzymes in human skin. $\mathrm{Br} \mathrm{J}$ Dermatol $133,371-376$.

DOI: 10.1111/j.1365-2133.1995.tb02663.x

75. Liu, S., and Yamauchi, H. (2008). Different patterns of 5alpha-reductase expression, cellular distribution, and testosterone metabolism in human follicular dermal papilla cells. Biochem Biophys Res Commun $368,858-864$.

DOI: $10.1016 /$ j.bbrc.2008.01.130

76. Andersson, S., Berman, D. M., Jenkins, E. P., and Russell, D. W. (1991). Deletion of steroid 5 alpha-reductase 2 gene in male pseudohermaphroditism. Nature 354, 159161. DOI: $10.1038 / 354159 \mathrm{a} 0$

77. Wilson, J. D., Griffin, J. E., and Russell, D. W. (1993). Steroid 5 alpha-reductase 2 deficiency. Endocr Rev 14, 577-593.

DOI: $10.1210 /$ er.14.5.577

78. Randall, V. A. (1994). Androgens and human hair growth. Clin Endocrinol (Oxf) 40, 439457.

DOI: 10.1111/j.1365-2265.1994.tb02483.x

79. Hamada, K., and Randall, V. A. (2006). Inhibitory autocrine factors produced by the mesenchyme-derived hair follicle dermal papilla may be a key to male pattern baldness. Br J Dermatol 154, 609-618. DOI: 10.1111/j.1365-2133.2006.07144.x

80. Van Scott, E. J., and Ekel, T. M. (1958). Geometric relationships between the matrix of the hair bulb and its dermal papilla in normal and alopecic scalp. J Invest Dermatol 31, 281-287. DOI: 10.1038/jid.1958.56

81. Stumpf, W. E., and Sar, M. (1976). Autoradiographic localisation of estrogen, androgen, progestin and glucocorticoid in target tissues and non-target tissues. In: Modern Pharmacology and Toxicology, Volume 8, Receptors and mechanism of 
action of steroid hormones., J. Pasqualini, ed. (New York: Marcel Dekker) pp. 41-84.

82. Choudhry, R., Hodgins, M. B., Van der Kwast, T. H., Brinkmann, A. O., and Boersma, W. J. (1992). Localization of androgen receptors in human skin by immunohistochemistry: implications for the hormonal regulation of hair growth, sebaceous glands and sweat glands. J Endocrinol 133, 467-475.

DOI: $10.1677 /$ joe.0.1330467

83. Thornton, M., Taylor, A. H., Mulligan, K., Al-Azzawi, F., Lyon, C. C., O'Driscoll, J., and Messenger, A. G. (2003). The distribution of estrogen receptor beta is distinct to that of estrogen receptor alpha and the androgen receptor in human skin and the pilosebaceous unit. J Investig Dermatol Symp Proc 8, 100-103.

DOI: 10.1046/j.1523-1747.2003.12181.x

84. Hibberts, N. A., Howell, A. E., and Randall, V. A. (1998). Balding hair follicle dermal papilla cells contain higher levels of androgen receptors than those from non-balding scalp. J Endocrinol 156, 59-65.

DOI: $10.1677 /$ joe.0.1560059

85. Thornton, M. J., Hibberts, N. A., Street, T., Brinklow, B. R., Loudon, A. S., and Randall, V. A. (2001). Androgen receptors are only present in mesenchyme-derived dermal papilla cells of red deer (Cervus elaphus) neck follicles when raised androgens induce a mane in the breeding season. $J$ Endocrinol 168, 401-408. DOI: 10.1677/joe.0.1680401

86. Ando, Y., Yamaguchi, Y., Hamada, K., Yoshikawa, K., and Itami, S. (1999). Expression of mRNA for androgen receptor, 5alpha-reductase and 17beta-hydroxysteroid dehydrogenase in human dermal papilla cells. Br J Dermatol 141, 840-845.

DOI: 10.1046/j.1365-2133.1999.03156.x

87. Asada, Y., Sonoda, T., Ojiro, M., Kurata, S., Sato, T., Ezaki, T., and Takayasu, S. (2001). 5 alpha-reductase type 2 is constitutively expressed in the dermal papilla and connective tissue sheath of the hair follicle in vivo but not during culture in vitro. J Clin Endocrinol Metab 86, 2875-2880.
88. Itami, S., Kurata, S., and Takayasu, S. (1990). 5 alpha-reductase activity in cultured human dermal papilla cells from beard compared with reticular dermal fibroblasts. J Invest Dermatol 94, 150-152.

DOI: 10.1111/1523-1747.ep12874003

89. Thornton, M. J., Hamada, K., Messenger, A.G., and Randall, V.A. (1998). Beard, but not scalp, dermal papilla cells secrete autocrine growth factors in response to testosterone in vitro. J Invest Dermatol 111, 727-732.

DOI: 10.1046/j.1523-1747.1998.00396.x

90. Itami, S., Kurata, S., Sonoda, T., and Takayasu, S. (1995). Interaction between dermal papilla cells and follicular epithelial cells in vitro: effect of androgen. $\mathrm{Br} \mathrm{J}$ Dermatol 132, 527-532.

91. Itami, S., and Inui, S. (2005). Role of androgen in mesenchymal epithelial interactions in human hair follicle. J Investig Dermatol Symp Proc 10, 209-211. DOI: 10.1111/j.1087-0024.2005.10107.x

92. Hibberts, N. A., and Randall, V. A. (1996). Testosterone inhibits the capacity of cultured balding scalp dermal papilla cells to produce keratinocyte mitogenic factors., In: Hair Research for the next Millennium, D. Van Neste, and V. A. Randall, eds. (Amsterdam: Elsevier Science) pp. 303-306

93. Sengel, P. (1983). Epidermal-dermal interactions during formation of skin and cutaneous appendages, In Biochemistry and physiology of the skin, L. A. Goldsmith, ed. (Oxford University Press, New York), pp. 102-131.

94. McElwee, K., and Hoffmann, R. (2000). Growth factors in early hair follicle morphogenesis. Eur J Dermatol 10, 341-350.

95. Carpenter, G., Liao, H. J. (2009). Trafficking of receptor tyrosine kinases to the nucleus. Exp Cell Res. 315, 1556-66 DOI: 10.1016/j.yexcr.2008.09.027

96. Paus, R. (2000). Control of the hair follicle growth cycle, In Hair and its disorders: biology, pathology and management, F. M. Camacho, Randall, V.A., and Price, V.H., ed. (Martin Dunitz, London), pp. 83-94. DOI: $10.1201 / \mathrm{b} 14711-9$ 
97. Philpott, M. (2000). The roles of growth factors in hair follicles: investigations using cultured hair follicles, In Hair and its disorders: biology, pathology and management, F. M. Camacho, Randall, V.A., and Price, V.H., ed. (Martin Dunitz, London), pp. 103-113. DOI: 10.1201/b14711-11

98. Philpott, M. P., Sanders, D. A., and Kealey, T. (1994). Effects of insulin and insulin-like growth factors on cultured human hair follicles: IGF-I at physiologic concentrations is an important regulator of hair follicle growth in vitro. J Invest Dermatol 102, 857861. DOI: 10.1111/1523-1747.ep12382494

99. Liu, J. P., Baker, J., Perkins, A. S., Robertson, E. J., and Efstratiadis, A. (1993). Mice carrying null mutations of the genes encoding insulin-like growth factor I (Igf-1) and type 1 IGF receptor (Igf1r). Cell 75, 59-72.

DOI: $10.1016 / \mathrm{s} 0092-8674(05) 80084-4$

100. Itami, S., Kurata, S., and Takayasu, S. (1995). Androgen induction of follicular epithelial cell growth is mediated via insulin-like growth factor-I from dermal papilla cells. Biochem Biophys Res Commun 212, 988994. DOI: 10.1006/bbrc.1995.2067

101. Philpott, M. P., Green, M. R., and Kealey, T. (1990). Human hair growth in vitro. J Cell Sci 97, 463-471.

102. Inui, S., Fukuzato, Y., Nakajima, T., Yoshikawa, K., and Itami, S. (2003). Identification of androgen-inducible TGFbeta1 derived from dermal papilla cells as a key mediator in androgenetic alopecia. J Investig Dermatol Symp Proc 8, 69-71.

DOI: 10.1046/j.1523-1747.2003.12174.X

103. Foitzik, K., Lindner, G. M., Mueller-Roever, S., Maurer, M., Botchkareva, N., Botchkareva, V., Metz, M., Hibino, T., Soma, T., Paolo dotto, G., Paus, A. (2000). Control of murine hair follicle regression (catagen) by TGF-b1 in vivo. Faseb $J$ 14, 752-760.

104. Tsuji, Y., Denda, S., Soma, T., Raftery, L., Momoi, T., and Hibino, T. (2003). A potential suppressor of TGF-beta delays catagen progression in hair follicles. J Investig Dermatol Symp Proc 8, 65-68. DOI: $10.1046 / j .1523-1747.2003 .12173 . x$
105. Hibino T., and Nishiyama T. (2004). Role of TGF-B2 in the human hair cycle. J Dermatol Sci 35, 9-18. DOI: $10.1016 /$ j.jdermsci.2003.12.003

106. Soma, T., Tsuji, Y., and Hibino, T. (2002). Involvement of transforming growth factorbeta2 in catagen induction during the human hair cycle. J Invest Dermatol118, 993-7. DOI: 10.1046/j.1523-1747.2002.01746.x

107. Grichnik, J. M., Burch, J. A., Burchette, J., and Shea, C. R. (1998). The SCF/KIT pathway plays a critical role in the control of normal human melanocyte homeostasis. J Invest Dermatol 111, 233-238.

DOI: 10.1046/j.1523-1747.1998.00272.x

108. Fleischman, R. A., Saltman, D. L., Stastny, V., and Zneimer, S. (1991). Deletion of the ckit protooncogene in the human developmental defect piebald trait. Proc Natl Acad Sci U S A 88, 10885-10889.

109. Randall, V. A., Jenner, T. J., Hibberts, N. A., De Oliveira, I. O., and Vafaee, T. (2008). Stem cell factor/c-Kit signalling in normal and androgenetic alopecia hair follicles. J Endocrinol 197, 11-23.

DOI: 10.1073/pnas.88.23.10885

110. Hibberts, N. A., Messenger, A. G., and Randall, V. A. (1996). Dermal papilla cells derived from beard hair follicles secrete more stem cell factor (SCF) in culture than scalp cells or dermal fibroblasts. Biochem Biophys Res Commun 222, 401-405.

DOI: $10.1006 /$ bbrc.1996.0756

111. Randall, V. A., Jenner, T.J., and De Oliveira, I. (2001). The human hair follicle contains several populations of melanocyte-lineage cells with differential expression of three melanocyte-lineage markers c-kit and Bc1-2. J Invest Dermatol.

112. Montagna, W., and Van Scott, E. J. (1958). The anatomy of the hair follicle, In The biology of hair growth, W. Montagna, and Ellis, R.A., ed. (Academic Press, New York), pp. 39-64.

DOI: 10.1016/B978-1-4832-3287-4.50009-X

113. Lachgar, S., Charveron, M., Bouhaddioui, N., Neveux, Y., Gall, Y., and Bonafe, J. L. (1996). Inhibitory effects of bFGF, VEGF and minoxidil on collagen synthesis by 
cultured hair dermal papilla cells. Arch Dermatol Res 288, 469-473. DOI: $10.1007 / \mathrm{BF} 02505237$

114. Lachgar, S., Charveron, M., Ceruti, I., Lagarde, J.M., Gall, Y., and Bonafe, J. L. (1996). VEGF mRNA expression in different stages of the human hair cycle: analysis by confocal laser microscopy. In: Hair research for the next Millenium, D. Van Neste, and V. A. Randall, edc. (Amsterdam: Elsevier) pp. 407-411.
115. Aslan, G., Cimen, S., Yorukoglu, K., Tuna, B., Sonmez, D., Mungan, U., and Celebi, I. (2005). Vascular endothelial growth factor expression in untreated and androgendeprived patients with prostate cancer. Pathol Res Pract 201, 593-598.

DOI: 10.1016/j.prp.2005.07.003 